\title{
A review on plant population study in maize crop
}

\author{
Farhan Ahmad, Muhammad Rabnawaz Khan, Muhammad Shafi, Junaid \\ Ahmad*, Sarmad Iqbal, Sayed Minhaj Ali Shah, Muhammad Tauseef, \\ Manzoor Ahmad, Mehran Ali, Abbas Saleem, Nasrullah, Zahid \\ Mehmood, Khalil Ur Rehman, Abdur Rauf Khan and Abidullah \\ Department of Agronomy, Faculty of crop production sciences, University of Agriculture Peshawar-Pakistan \\ *Corresponding author's email:junaid.agri@aup.edu.pk \\ Citation \\ Farhan Ahmad, Muhammad Rabnawaz Khan, Muhammad Shafi, Junaid Ahmad*, Sarmad Iqbal, Sayed Minhaj Ali \\ Shah, Muhammad Tauseef, Manzoor Ahmad, Mehran Ali, Abbas Saleem, Nasrullah, Zahid Mehmood, Khalil Ur \\ Rehman, Abdur Rauf Khan and Abidullah. A review on plant population study in maize crop. Pure and Applied \\ Biology. Vol. 9, Issue 1, pp162-171. http://dx.doi.org/10.19045/bspab.2020.90020
}

\begin{tabular}{llll}
\hline \hline Received: 07/06/2019 & Revised: 06/09/2019 & Accepted: 13/09/2019 & Online First: 04/10/2019
\end{tabular}

\section{Abstract}

A review study on plant population was done to assess the optimum population for improved grain yield and biological yield. The main perspective of this review study to evaluate the different planting population and to recommend it for future application. The increasing consumption of maize contributes a prominent place in economy of agriculture. The significance of planting density as a feature defining yield and growth has remained well recognized for the key areas of production of maize. Defining maize density reaction is a frequent part of study but it is unreliable across management practices and diverse environment. The grain yield of maize rise from 10.1 to $10.8 \mathrm{tha}^{-1}$ as population rise from 59000 to 89000 plants ha $^{-1}$. The grain yield of maize normally reveals a quadratic comeback to planting population with a rise through a series of lower populations, a steadily reducing amount of yield increase comparative to population rise and lastly a yield plateau at certain reasonably higher populations of plant. Planting density influenced generally maize growth parameters in most promising growth condition and therefore it is measured as a vital aspect to regulate the range of interplant competition. Optimal planting density enlarged number of grains per cob, 1000-grain weight and eventually improved maize grain yield. This paper has reviewed the research work performed by numerous scientists in Pakistan and abroad.

Keywords: Economy; Grain yield; Maize; Plant population

\section{Introduction}

Corn (Zea mays L.) comes in the family of Poaceae. Maize plant forms key dietary measure of many people in the form of porridge, bread and cake. Further it is a key grain food consumption of human [1]. One of the supreme main active causes is no use of finest planting density per hectare [2].
Greater planting densities upsurge sterility of plant and the interval among female and male blooms, and lessen the grains number per ear [3]. Planting density studies are too attractive for at least two causes for researchers of maize. Suitable population can add to substantial yield of grain rises for farmers [4]. Furthermore, yield of maize reaction to 
density hang on environmental and genotypic influences [5], and moreover the damaging comebacks to a certain factor of the crop can be confirmed beyond some restrictions. Stand populations influences architecture of plant, modifies growth and developmental designs and affects partition and production of carbohydrate [6]. Maize is sensitive to distinctions in population of plant than further family of grass members [7]. At lower populations, various recent hybrids of maize deprived of tiller effectively and relatively often give one ear per plant. Thus, maize do not share the most tillering attribute grasses of recompensing for smaller area of leaf and smaller reproductive components by branching [8]. Denser planting density will provide lesser space for competing weeds in between crop rows [9]. Moreover the use of dense populations improves interplant competition for nutrients, water and light. Plant population is one of the essential features that upset maize yield of grain, being promising to rise yield of maize, average rate of grain-filling and water use efficiency [9]. Judicious density of maize is the center for producing effective population organization that includes appropriate leaf area index and creates full use of light energy for enriched photosynthetic capacity of leaf [10]. Though, if the population is too excessive it will decrease the light ability to enter the lower canopy [11], causing senescence of the lower leaves earlier [12] and lessening the utilization efficiency of radiation [13]. The review study was carried out to evaluate different planting population and to compare the yield of these populations. To know about the proper population that will leads towards maximum yield and to practice them in future upcoming researches. The review study of different population will lead us to know which population is optimum for greater yield so that researcher may apply them.

In May 2019 literature reviews were together on diverse feature about maize planting density. The determination of this review study was to identify the dissimilar density practices of planting on yield quality and maize growth. The appropriate and significant published work accessible on maize has been studied.

\section{Influence of planting density on maize growth}

Leaf area plant $^{-1}$ declined, while leaf area index rises in right manner with rise in planting density. By increasing density we condensed the space among plants and subsequently increase intraspecific competition, which as an end result decrease the plants individual size in terms of leaves number, total leaf area and size of leaf [14]. Moreover, increasing density of plant increased maize LAI. [15] Initiated that height of plant improved with rises in density up to 10 plants $\mathrm{m}^{-2}$. Greater plant populations lead to the weaker plants of more size which prone to lodging and diseases and resulted in lower yield of grains [16]. [17] Find the taller plant with the maximum planting density. [18] Who conveyed that increasing planting density increased ears $\mathrm{m}^{-2}$ and declined cobs per plant. They stated that the cobs number per plant was reduced significantly probably due to more light, nutrients and aeration competition and thus allowing the plants in these treatments to endure reproductive growth lesser. [19] Concluded that the length of cob reduced by rise in planting density. These findings specify that there is a positive association among length of cob and spacing of plant in maize, possibly due to variable competition of plant. [3] Initiated that length of cob gets reduction by an increase of planting density. [20] Perceived that as plant population increased the diameter of stem reduced, an inverse relationship between stem diameter and plant population was found. Decline in diameter of stem as a result of higher planting densities might be due to greater competition of plant for existing resources like water, air, nutrients and space. 
Competition of plant decreases water and nutrient uptake that eventually diminishes production of assimilates and their supply towards stem. [21] Described that diameter of stem were lesser in higher plant populations as a consequence of interplant competition. [22] Directed that the consequence is largely due to competition for nutrients of soil, light and moisture. In research, it was detected that plant density of maize at 80,000 plants $\mathrm{ha}^{-1}$ used strong influence on height of maize, lodging percent and diameter of stalk. [23] Explained the detected tendency of height of plant and length of internodes with rising in planting density for light competition. Moreover the fashion perceived for diameter of stalk and lodging percent with rise in density of maize plant. Maize plants become more susceptible to stalk lodging as plant density increases [24]. [25] Resulted from the study that the highest physiological growth indices were attained in higher planting population, as photosynthesis rises by development of leaves area and rises TDW. Planting density has vital effects on reproductive and vegetative maize growth. Maize physiological development indices are lower with low planting density because of smaller leaf area per plant plasticity. [26] Found that maturity overdue with the planting density increases. The tough interplant competition at greater densities for nutrients, water and light might have extended the vegetative development of the plants as related to lower planting densities. This proposed that denser populations may have marginally reduced down the plant rate development as of more competition in higher density. [27] Plants will produce smaller ears, fewer kernels per ear and/or less grain weight per year in densely sown crops, but greater number of ear will result in a higher yield. [28] Exposed that due to crowding effect of the plant and greater intraspecific competition for resources increases. Plants number rises in a particular area the competition amongst the plants for capture of light and uptake of nutrients also increased that resulted in taller plants. The practice of lower than optimum planting density delays closure of canopy, declining seasonal capture of incident solar radiation, leading to great production of grain per plant but low production per area of grain [27].

\section{Influence of planting density on maize yield}

Grain yield per unit area rises with planting density till the rise in attributes of yield to plants is decreases by decline in mean yield per plant [28]. Lower than optimal populations suffer closure of canopy with reduced capture of seasonal incident of solar radiation, prominent to larger grains number per plant, but lower grain yield per unit area. [29] Described that biological yield enlarged with the increase of planting density. [30] Obtained higher biological yield at 80,000 and 95,000 plants $\mathrm{ha}^{-1}$ respectively as compared with 55000 and 60000 plants ha ${ }^{-1}$. [31] Reported that grain rows and number of rows ear ${ }^{-1}$ changed significantly due to greater planting population. In the same approach, several researchers perceived that grains per ear frequently decrease with rise in plant population. [32] Plant biomass was increased with increasing plant density, whereas harvest index with a downward tendency. [33] Resulted that increase in biological yield at higher density of planting might be due to rise in number of plants as well as in height of plant of single plants at denser populations. [33] Reported greater biological yield at higher planting density in maize crop. [19] Revealed that weight of 1000-grains increased with reducing planting density in maize. [34] Stated that there were varietal dissimilarities in 1000-grain weight that increased with the rising in plant spacing. [35] Reported unreliable optimal density levels of plants ranging from 86000 to 101270 plants $\mathrm{ha}^{-1}$ for corn grain yield. [36] Who conveyed that yield of fodder increased 
with rise in planting density. [37] Who concluded that use of higher planting density reduced size of grain, number of grains per row and grains number per plant. High plant population beyond optimal leads to extreme interplant competition for occurrence of photosynthetic photon flux density, soil water and nutrients of soil. This outcomes in partial supplies of nitrogen and carbon and resulting barrenness increases and kernel number per plant and size of kernel decreases. [38] Who perceived that cobs number, cobs weight and weight of grain per cob were maximum at wide spacing. [39] Who described that weight of thousand grains increased when population in maize decreased. [40] Revealed an increased kernel yield with planting density up to 51,000 plants ha ${ }^{-1}$, followed by yield decreasing with more rises of population up to 72,000 plants $\mathrm{ha}^{-1}$. Reproductive response of maize to plant density has normally displayed that yield of individual plant decreases as plant per unit area rises [41]. [42] Resulted that population of maize for maximum economic yield of grain diverges among 30,000 to 90,000 plants $\mathrm{ha}^{-1}$. Coefficient of Variance of grain yield through the four grown seasons were increased with the increasing plant density [43]. Using of high planting densities may decrease the photosynthates, nitrogen supply and water to developing ear. High stand establishment creates competition for nutrients, aeration, light and subsequently causing the plants to endure fewer reproductive growth [43]. [44] Reported that optimum density of plant gave greater yield due to soil nutrients utilization more powerfully joined with further factors regarding growth. They also detected lower yield of grain with highest density as of smaller size of ear, less ears number plant $^{-1}$ due to more competition for factors regarding growth. Grain yield and WUE both showed parabolic relations with plant density [45].

1)

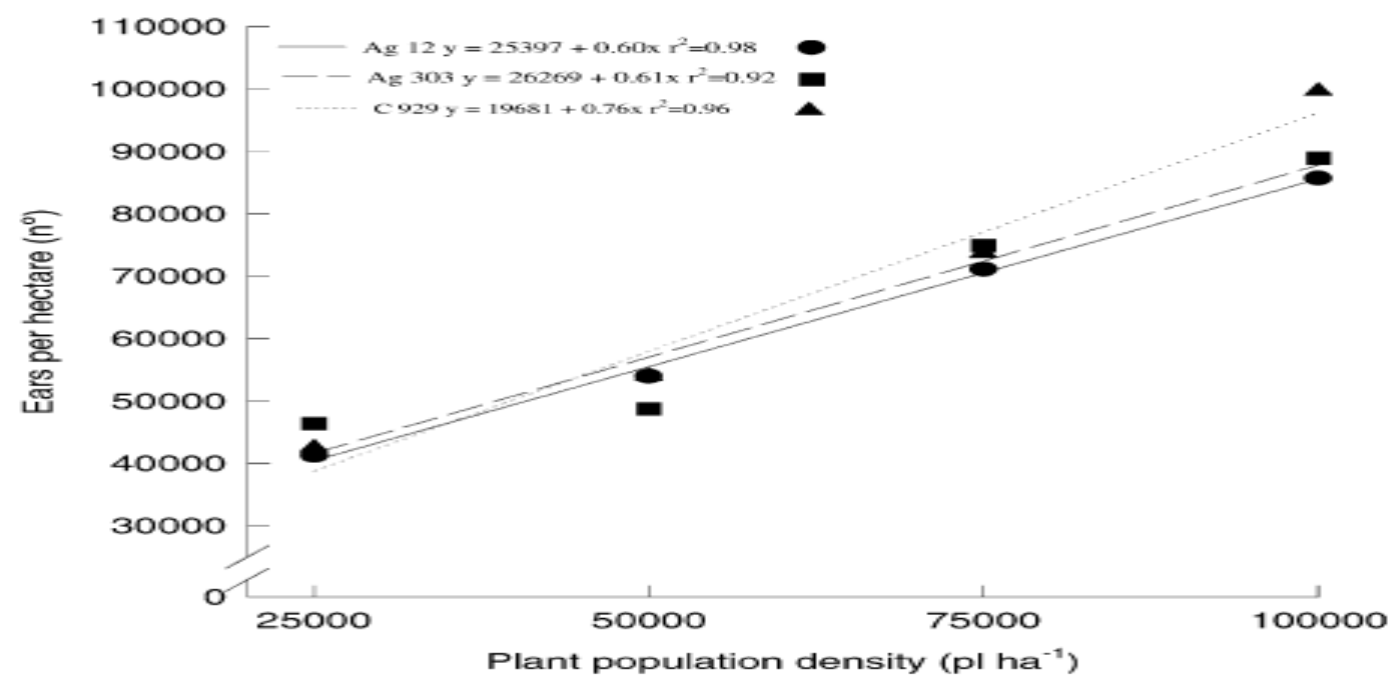


Pure Appl. Biol., 9(1): 162-171, March, 2020

http://dx.doi.org/10.19045/bspab.2020.90020

2)

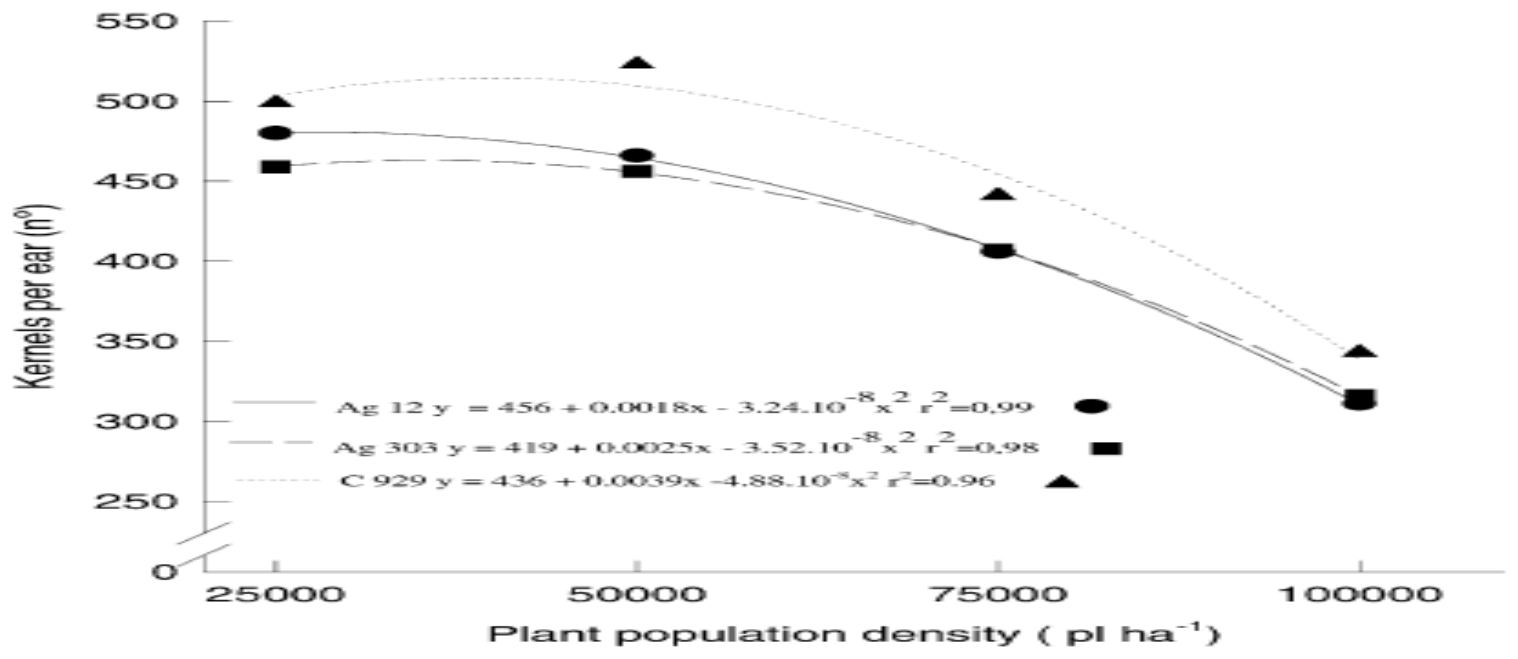

3)

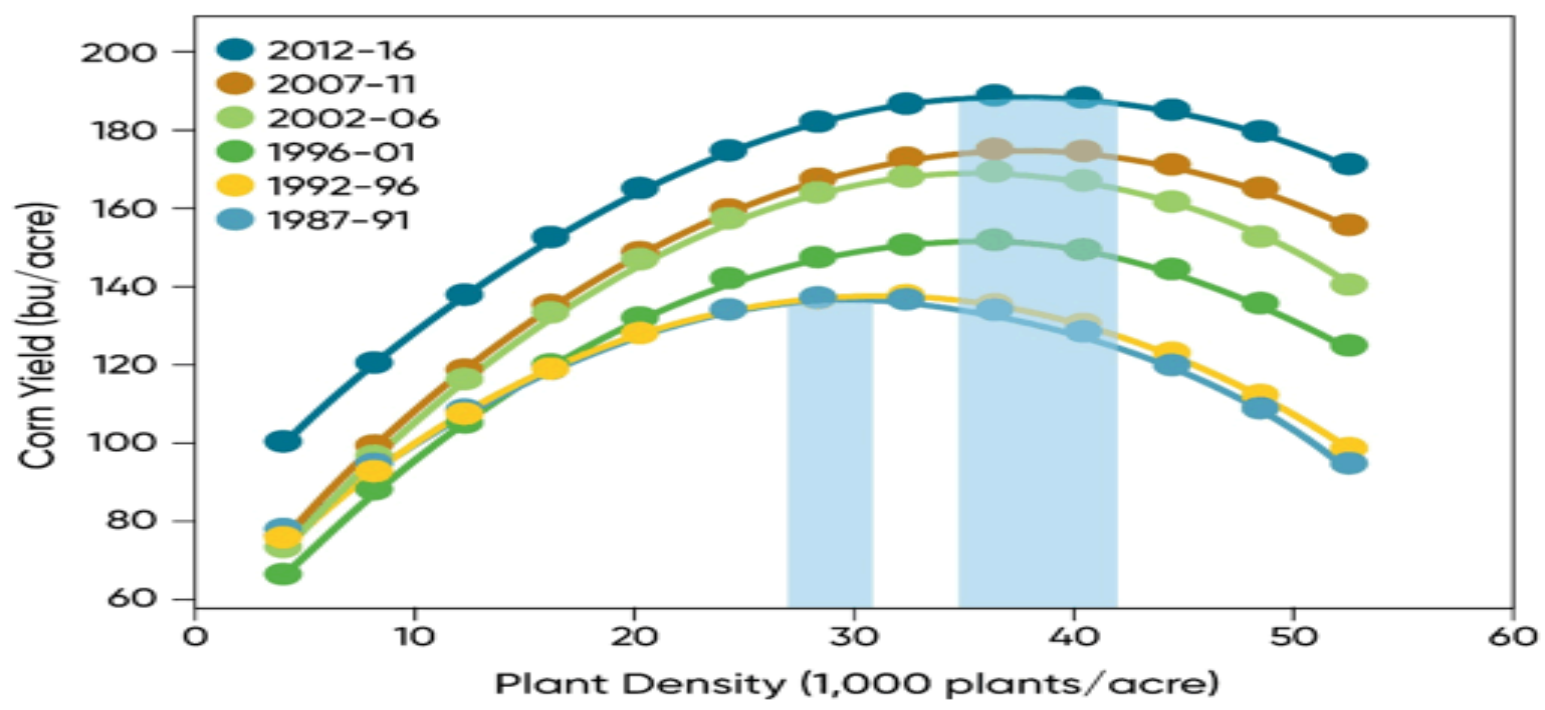


4)

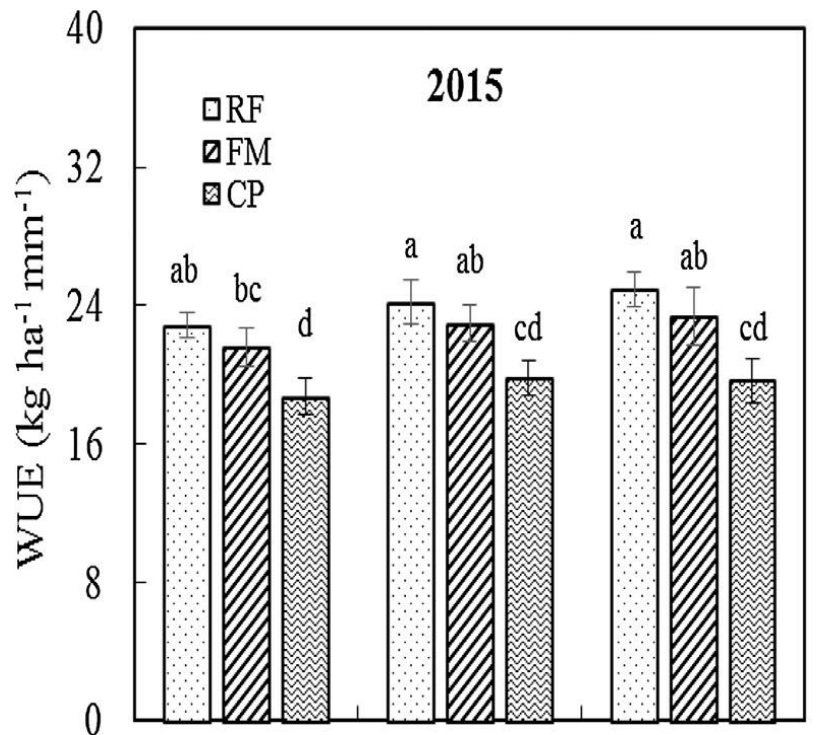

Low density Middle density High density

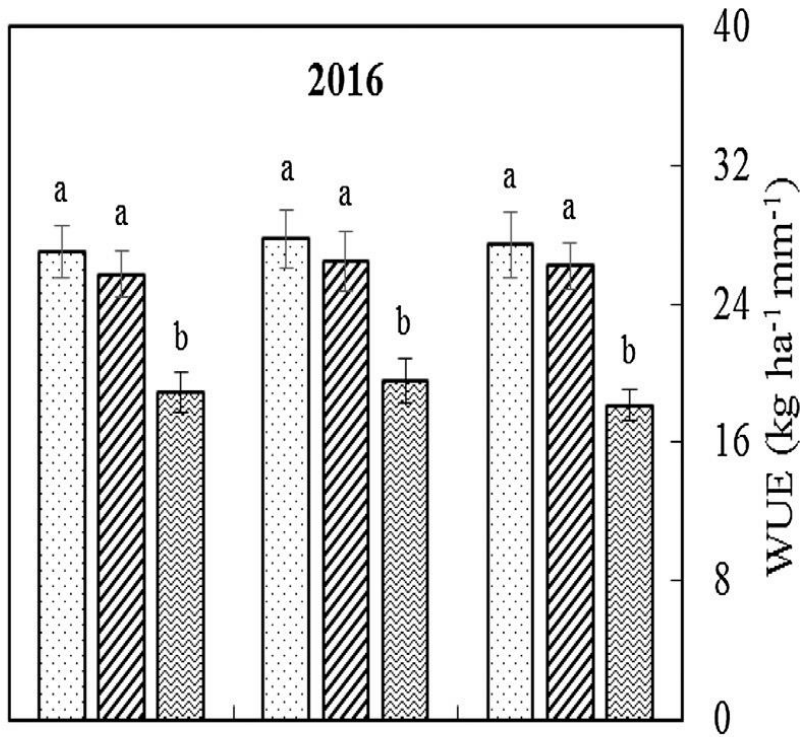

Low density Middle density High density

5)

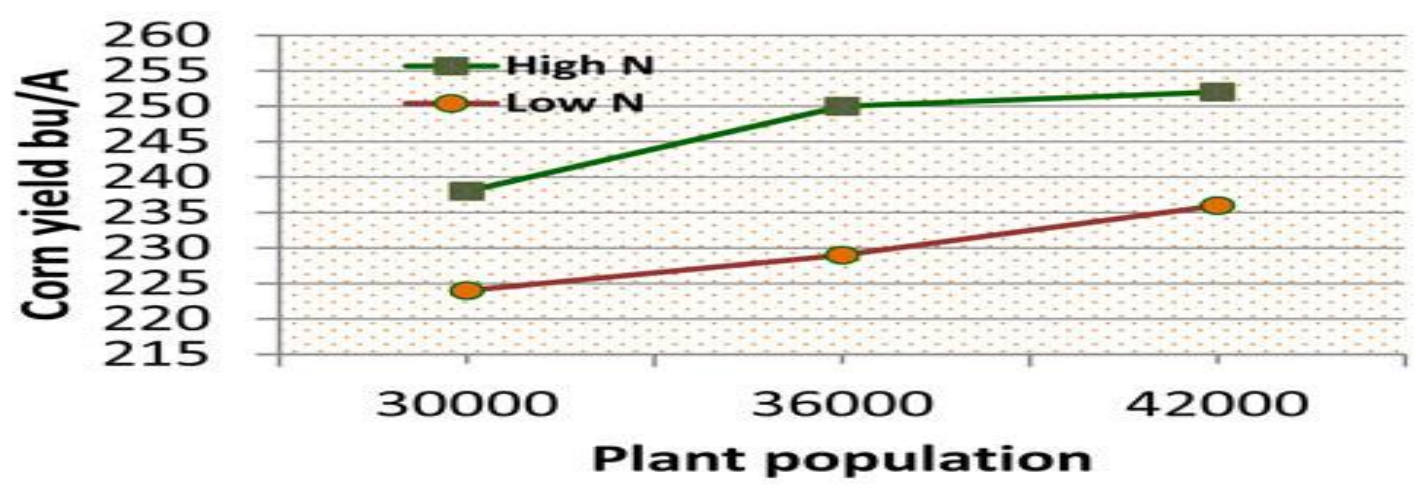

6)

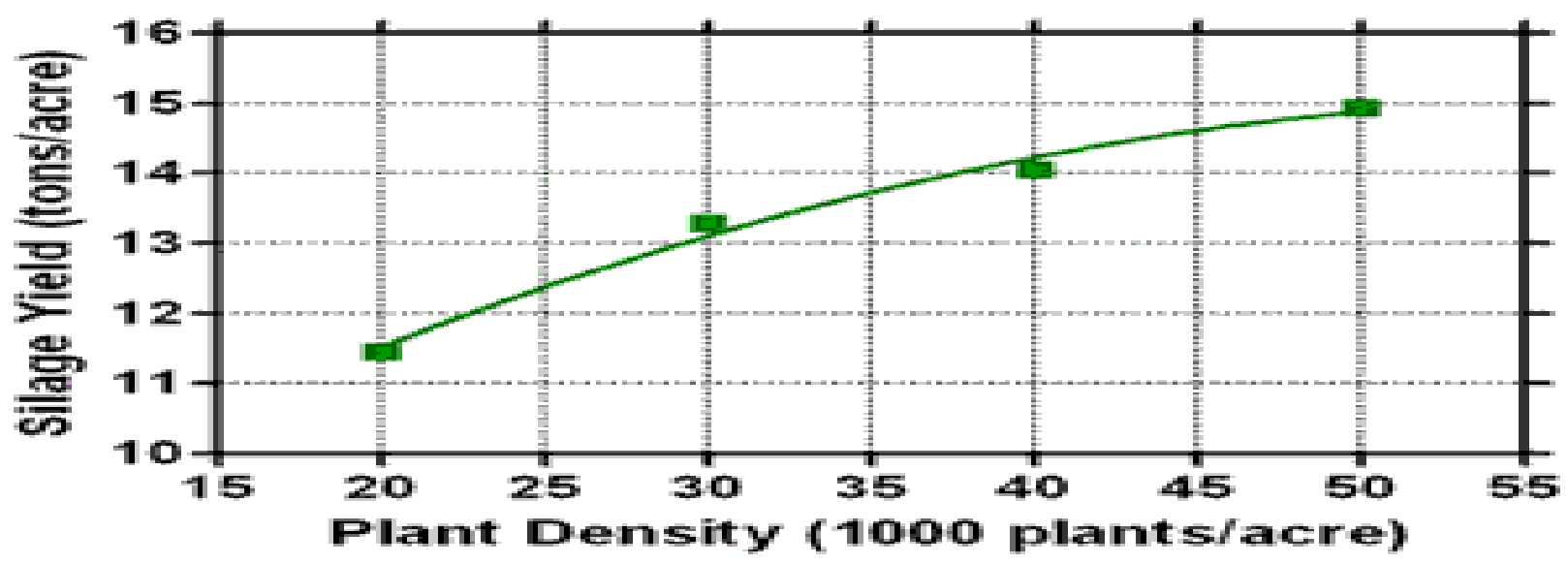


7)

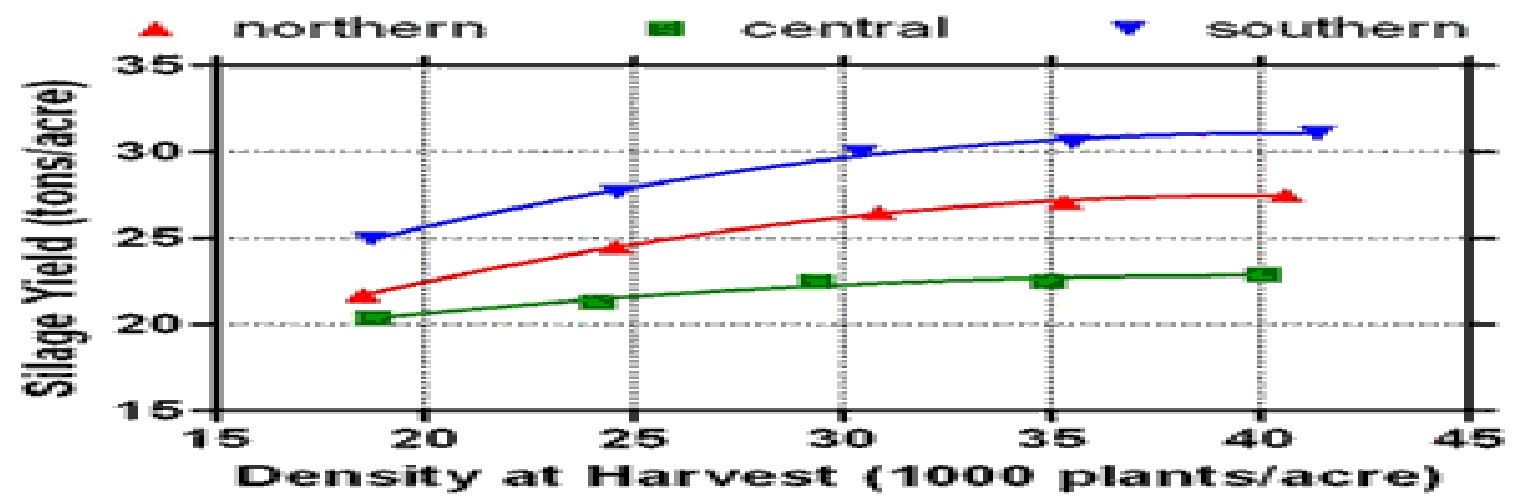

8)

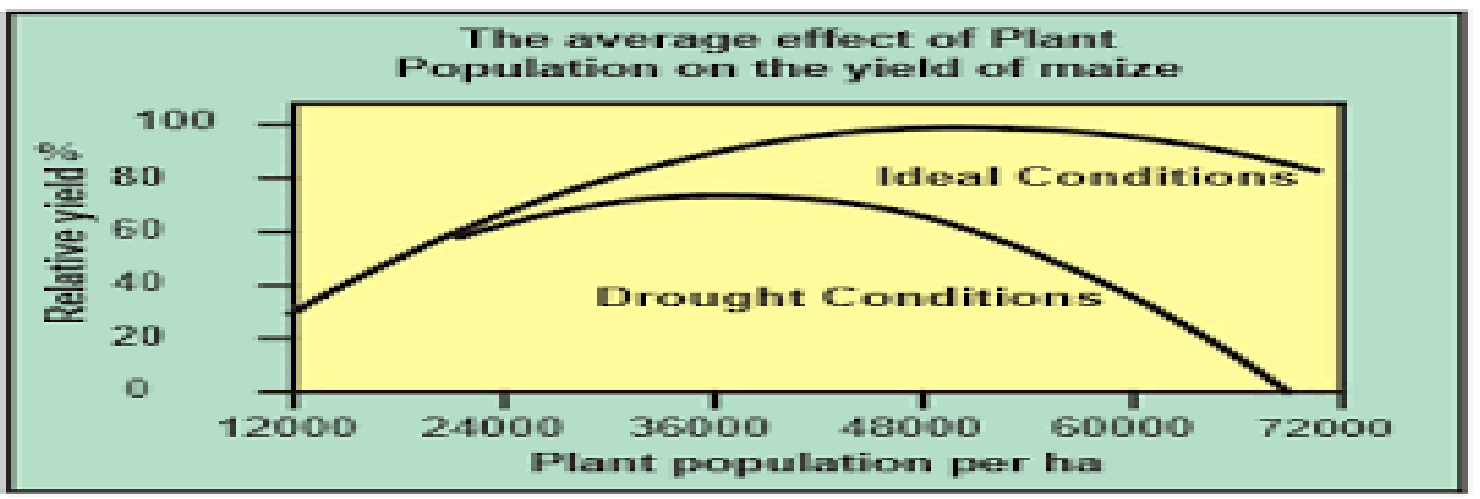

9)
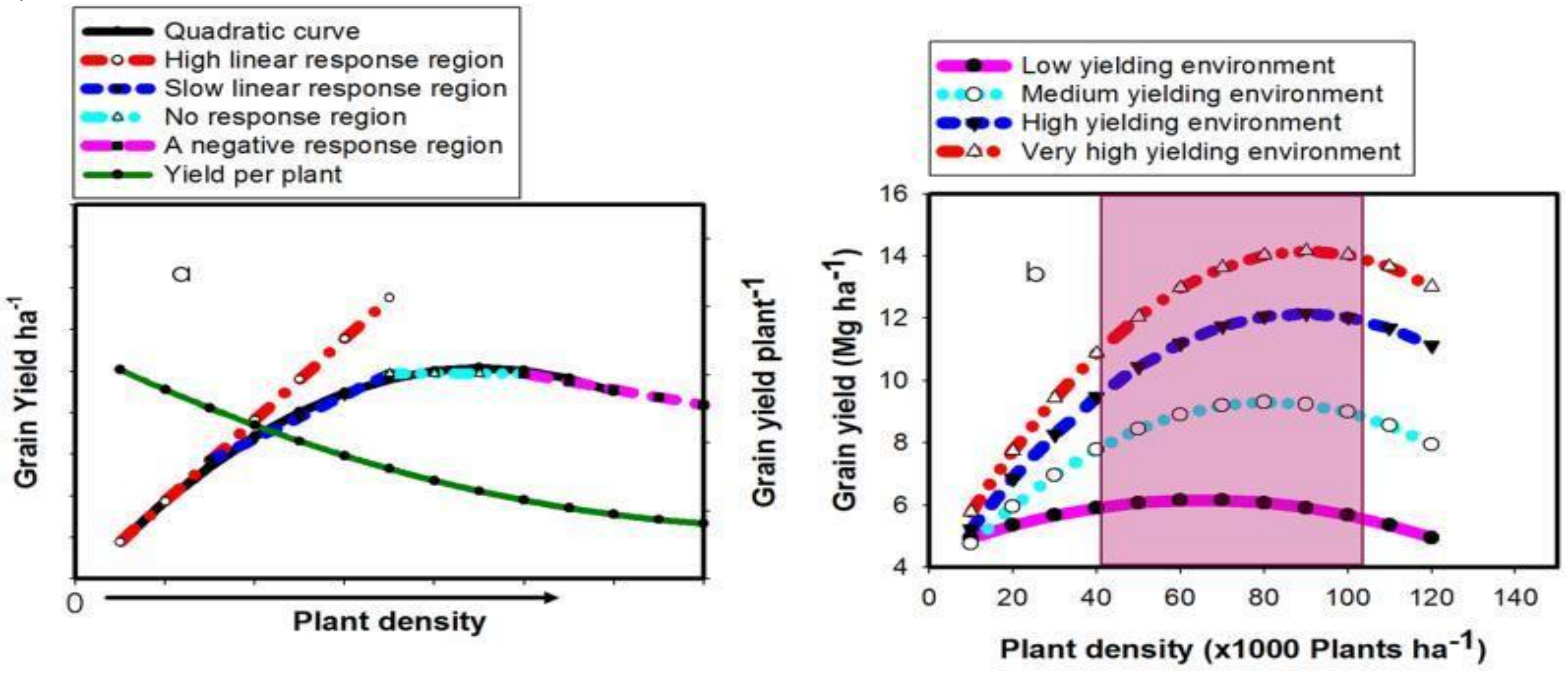
10)

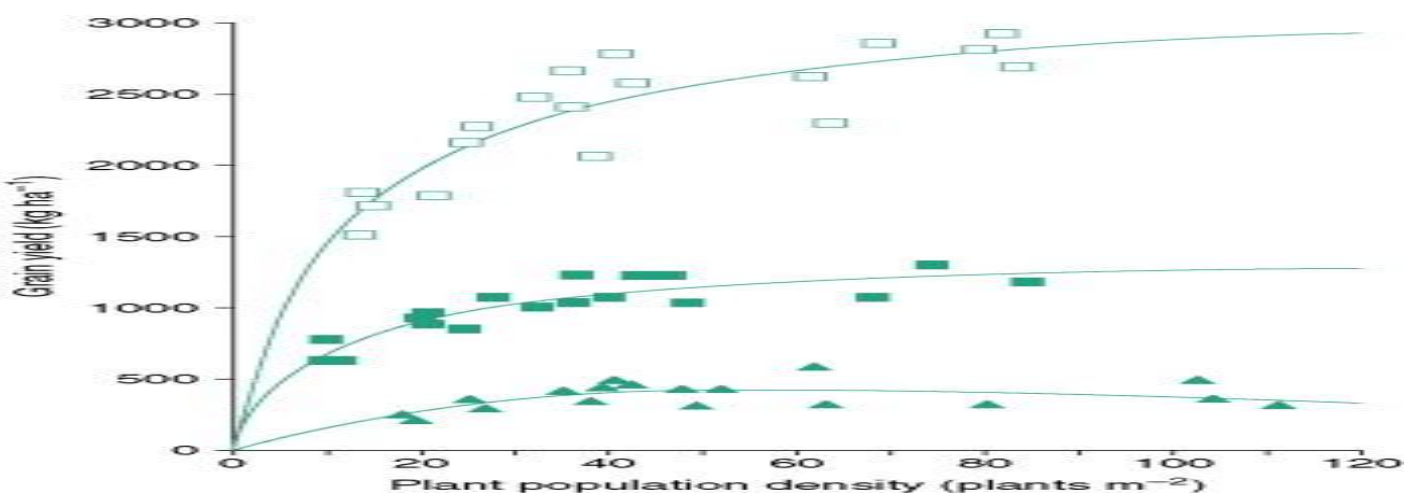

Figures 1-10. Some of the results in the form of figures from different researches are presented from 1 to 10 .

\section{Conclusion}

Planting density ultimately affects the growth and development of maize crop. The application of planting density up to 90000 plants $\mathrm{ha}^{-1}$ increase the growth traits, yield and yield components of maize. High planting density increases plant height, grain yield and biological yield. This study of various literature it can be concluded that planting density from 60000 to $90000 \mathrm{ha}^{-1}$ should be practiced for achieving high yield.

\section{Authors' contributions}

Conceived and designed the experiments: $F$ Ahmad, MR Khan \& M Shafi, Performed the experiments: F Ahmad, J Ahmad, S Iqbal \& SMA Shah, Analyzed the data: Z Mehmood, KU Rehman, AR Khan \& Abidullah, Contributed materials/ analysis/ tools: M Tauseef, M Ahmad, M Ali \& A Saleem, Wrote the paper: F Ahmad, M Shafi \& J Ahmad

\section{References}

1. Ahmad A, Bukhsh MA, Ahmad R, Zahid A \& Ghafoor A (2008). Production potential of three maize hybrids as influenced by varying plant density. Pak $J$ Agri Sci 45(4): 413-417.

2. Sangoi LR \& Salvador J (1998). Influence of plant height and of leaf number on maize production at high plant densities. Agron J 33: 297-306.

3. Sangoi L, Gracietti MA, Rampazzo C \& Bianchetti P (2002). Response of Brazilian maize hybrids from different ears to changes in plant density. Field Crops Res 79: 39-51.

4. Cardwell VB (1992). Fifty years of Minnesota corn production: sources of yield increase. Agron J 74: 984-995.

5. Bondavalli B, Colyer D \& Kroth EM (1970). Effects of weather, nitrogen, and population on corn yield response. Agron $J$ 62: 669-672.

6. Casal JJ, Deregibus VA \& Sanchez RA (1985). Variations in tiller dynamics and morphology in Lolium multiflorum Lam. vegetative and reproductive plants as affected by differences in red/far-red irradiation. Annals of Bot Lon 56: 533-559.

7. Almeida ML \& Sangoi L (1996). Aumento da densidade de plantas de milho para regiões de curta estação estival de crescimento. Pesquisa Agropecuária Gaúcha, Porto Alegre 2(2): 79-183.

8. Gardner FP, Pearce RB \& Mitchell RL (1985). Physiology of crop plants. Ames: Iowa State University, pp 327.

9. Feng P, Shen X, Zheng H, Zhang H, Li Z \& Yang H (2014). Effects of planting density on kernel filling and dehydration characteristics for maize hybrids. Chinese Agric Sci Bull 30: 92-100.

10. Yang JS, Gao HY, Peng L, Geng LI, Dong ST \& Zhang JW (2018). Effects of planting density and row spacing on canopy apparent photosynthesis of high- 
yield summer corn. Acta Agron Sin 36: 1226-1235.

11. Liu J, Bu L, Zhu L, Luo S, Chen X \& Li S (2018). Optimizing plant density and plastic film mulch to increase maize productivity and water-use efficiency in semiarid areas. Agron J 106: 1138-1146.

12. Borras L, Maddonni GA \& Otegui ME (2003). Leaf senescence in maize hybrids: plant population: row spacing and kernel set effects. Field Crops Res 82: 13-26.

13. Lin P, Qi H, Li C \& Zhao M (2016). Optimized tillage practices and row spacing to improve grain yield and matter transport efficiency in intensive spring maize. Field Crops Res 198: 258-268.

14. Johnson DE \& Wilman D (1997). Effects of plant spacing and seed rate on leaf and grain production of maize (Zea mays L.) in N Belize. Tropical Agric 74(1): 12-17.

15. Griesh MH \& Yakout GM (2001). Effect of plant population density and nitrogen fertilization on yield components of some, white and yellow maize hybrids under drip irrigation system in Sandy soil. Inter $W J$ Horst 810-811.

16. Chandiposha M \& Chivende F (2014). Effect of ethephon and planting density on lodged plant percentage and crop yield in maize (Zea mays L.). African J of Plant Sci 8(2): 113-117.

17. Zhang J, Dong S, Wang K, Hu C \& Liu P (2006). Effects of shading on the growth, development and grain yield of summer maize. Ying Yong Sheng Tai Xue Bao. 17(4): 657-662.

18. Tyagi RC, Singh D and Hooda IS (1998). Effect of plant population, irrigation and nitrogen on yield and its attributes of spring maize (Zea mays L.). Indian Agron $J$ 43(4): 672-676.

19. Akcin A, Sade B, Tamkoc A \& Topal A (1993). Effect of different plant densities and nitrogen fertilization rates on the grain yield, yield components and some morphological traits of hybrid TTM- 813 grown at Kenya. Doga, Turk Turmve orrmanculik Dergisi. 17(1): 181-294.
20. Sener O, Gozubenli H, Konuskan O \& Kilinc M (2004). The effects of Intra-row spacings on the grain yield and some agronomic characteristics of maize (Zea mays L.) hybrids. Asian J Plant Sci 3: 429432.

21. Mobasser HR, Delarestaghi K, Tari A \& Pourkalhor DB (2007). Effect of planting density on agronomical characteristics of rice varieties in north of Iran. Pak J Biol Sci 10(18): 3205-3209.

22. Early EB, Melbrath WD, Seif RD \& Hageman RW (1967). Effect of shade applied at different stages of plant development on corn production. Crop Sci 7: 151-156.

23. Hunt IA, Wholey DW \& Cock JH (1997). Growth physiology of cassava (Manihot esculenta crantz). Field Crop Abstract 30(2): 77-89.

24. Valadabadi SA \& Hossein AF (2010). Effects of planting density and pattern on physiological growth indices in maize (Zea mays L.) under nitrogenous fertilizer application. $J$ of Agric Extension and Rural Devel 2(3): 040-047.

25. Ogunlela VB, Amoruwa GM \& Olongunde OO (2005). Growth, yield components and micronutrient nutrition of field maize grown as affected by nitrogen fertilization and plant density. Nutrient Cycl Agroecosys 17: 385-1314.

26. Sangakkara UR, Bandaranayake PSRD, Gajanayake JN \& Stamp P (2004). Plant populations and yield of rainfed maize grown in wet and dry seasons of the tropics. Maydica 49: 83-88.

27. Westgate ME, Forcella F, Reicosky DD \& Somsen J (2017). Rapid canopy closure for maize production in the northern US corn belt: radiation-use efficiency and grain yield. Field Crops Res 49: 249-258.

28. Tollenaar M \& Wu J (1999). Yield improvement in temperate maize is attributable to greater stress tolerance. Crop Sci 39: 1597-1604.

29. Gul B, Marwat KB, Hassan G, Khan A, Hashim S \& Khan IA (2009). Impact of tillage, plant population and mulches on 
biological yield of maize, Pak J Bot 41(5): 2243-2249.

30. Sikandar A, Ali M, Amin M, Bibi S \& Arif M (2007). Effect of plant population on maize hybrids. J Agric Biol Sci 2(1): 19906145.

31. Bavec F \& Bavec M (2002). Effects of plant population on leaf area index, cob characteristics and grain yield of early maturing maize cultivars (FAO 100-400). European J. Agron. 16: 151-159.

32. Hashemi AM, Herbert SJ \& Putnam DH (2005). Yield response of Corn to crowding stress. Agron J 97: 839-846.

33. Ammanullah, Shah $\mathrm{P} \&$ Marwat KB (2009). Nitrogen levels and its time of application influence leaf area, height and biomass of maize planted at low and high density. Pak J Bot (In Press).

34. Gozubenli H, Ulger \& and Sener O (2001). The effect of different nitrogen doses on grain yield and yield-related characters of some maize genotypes grown as second crop. J Agric Fac CU 16: 39-48.

35. Porter P, Hicks D, Lueschen W, Ford J, Warnes D and Hoverstad T (1997). Corn response to row width and plant population in the northern Corn Belt. $J$ Prod Agric 10(2): 293-300.

36. Roy SK and Biswas PK (1992). Effect of plant density and detopping following silking on cob growth, fodder and grain yield of maize (Zea mays L.). J Agric Sci Abstracted in Field Crop Abstract 46: 1498-1993.

37. Lemcoff JH \& Loomis RS (1994). Nitrogen and plant density influences on silk emergence, endosperm development, and grain yield of maize (Zea mays L.). Field Crops Res 38(1): 63-72.

38. Norwood CA (2007). Dry land corn in Western Kansas: Effects of hybrid maturity, planting date and plant population. Agron J 93: 540-547.

39. Akein AB, Sad M, Mukyiunand A \& Tankoc A (1994). Effect of different cycoccl and rate and different planting densities on grain yield, crude protein and some morphological characters of maize hybrid TTM-813. Doga. Turk, Tarumve Ormancilik Digrici 17(4): 1097-1111.

40. Prior CL \& Russell WA (2019). Yield performance on non-prolific and prolific maize hybrids at six plant densities. Crop Sci 15: 482-486.

41. Duncan WG (2018). The relationship between corn population and yield. Agron J 50: 82-84.

42. Olson RA \& Sanders DH (1988). Maize production. In: G.F. Sprague, J.W. Dudley. Corn and corn improvement. Madison: American Soc of Agron Cap11: 639-686.

43. Zamir MSI, Ahmad AH, Javeed HMR \& Latif T (2011). Growth and yield behaviour of two maize hybrids (Zea mays L.) towards different plant spacing. Cercetări Agronomice în Moldova 14(2): 33-40.

44. Akbar H, Shah P, Khan AZ, Saeed H \& Munir M (2016). Biomass, grain yield and harvest index as criteria for comparing corn types at different nitrogen levels and planting densities. Sarhad J Agric 12: 117121.

45. Yu C, Saravanakumar K, Xia H, Gao J, Fu K, Sun J, Dou K \& Chen J (2017). Occurrence and virulence of Fusarium spp. associated with stalk rot of maize in North-East China. Physiol and Mol Plant Pathol 98: 1-8. 